\title{
Стан системи антиоксидантного захисту в піддослідних тварин внаслідок модельованої поеднаної абдоміно-скелетної травми та ішемї̈-реперфузї нижніх кінцівок
}

\begin{abstract}
Мета роботи: вивчити вплив реперфузії кінцівки в моделі поєднаної абдоміно-скелетної травми на зміни показників антиоксидантного захисту.

Матеріали і методи. В експерименті використали 130 статевозрілих білих щурів-самців лінії Wistar масою 190-220 г, які знаходилися на стандартному раціоні віварію.

Усіх тварин поділили на групи: контрольну (КГ) та три дослідні (ГД): контрольна група - інтактні тварини (10 тварин); перша дослідна група (ГД-1) - моделювали перелом стегна, масивну зовнішню кровотечу та ішемію-реперфузію нижніх кінцівок (40 тварин); друга дослідна група (ГД-2) - моделювали перелом стегна, масивну зовнішню крововтрату та закриту травму органів черевної порожнини (40 тварин); третя дослідна група (ГД-3) - моделювали закриту травму органів черевної порожнини, скелетну травму, масивну зовнішню крововтрату та ішемію-реперфузію нижніх кінцівок (40 тварин).

Тварин дослідних груп виводили з експерименту в умовах тіопентало- натрієвого наркозу методом тотального кровопускання з серця через 3, 7, 14 та 21 добу після моделювання травм. Для дослідження забирали кров тварин.

У сироватці крові визначали активність каталази, та враховуючи отримані попередньо дані щодо вмісту реагентів до тіобарбітурової кислоти (ТБК-активних продуктів), розраховували антиоксидантно-прооксидантний індекс.

Результати досліджень та їх обговорення. Отримані результати дають змогу стверджувати, що реперфузія кінцівки зумовлює розвиток тривалого оксидативного стресу, у відповідь на який зростає рівень каталази. Найбільш виражені зміни зафіксовано у групі піддослідних тварин, де поряд з поєднаною абдоміно-скелетною травмою була наявна ішемія реперфузія нижніх кінцівок. Саме вона була причиною розвитку тривалих системних змін та відповідно дисбалансу адаптаційно-компенсаторних механізмів, спрямованих на ліквідацію патологічних чинників.

Поєднання абдоміно-скелетної травми та ішемії-реперфузії нижніх кінцівок викликає спричиняє оксидативний стрес та виснаження антиоксидантних систем, про що свідчить зниження рівня АПІ, який через 21 добу був статистично менше контрольних показників ( $<0,05)$ на $13,3 \%$.
\end{abstract}

Ключові слова: ішемія; реперфузія; джгут; експеримент; поєднана травма; каталаза; кровотеча.

Постановка проблеми і аналіз останніх досліджень та публікацій. Травма залишається однією з важливих питань медицини пошкоджень. Незважаючи на численні дослідження рівень травматизму та смертності залишається значним. Так, за прогнозами ВООЗ травми внаслідок ДТП будуть провідною причиною смерті до 2030 року. Основними причинами смерті серед травмованих залишається ЧМТ та кровотечі [1].

Окрему категорію серед травм займають поєднані травми, що ускладнені кровотечами, отриманими внаслідок бойових дій та при надзвичайних ситуаціях. Кровотечі за вищевказаних умов складають понад 40 \% випадків смерті на догоспітальному етапі та протягом перших 24 годин після поранення [2]. Також неконтрольована кровотеча $є$ другою провідною причиною смерті у травмованих за цивільних умов [2-5]. Коагулопатія, пов’язана з травмою, зумовлена метаболічним ацидозом, гіпотермією нерідко розвивається у травмованих та $є$ причиною смертельних випадків та пусковим механізмом багатьох ускладнень.
Згідно зі статистикою, приблизно 24 \% смертей, спричинених кровотечою, можна було запобігти $[6,7]$. Саме тому останнім часом активно застосовуються засоби контролю кровотечі, зокрема кровоспинні джгути. Однак незважаючи на очевидні переваги їх використання та відносну безпеку слід враховувати можливі наслідки їх використання.

Так, в експериментальних роботах показано, що накладання кровоспинних джгутів протягом двох годин призводило до пошкодження м'язів індикатором, внаслідок чого відбулося зростання таких продуктів метаболізму, як молочної кислоти та креатинфосфокінази. Хоча значна кількість наукових робіт вказує на безпечне використання джгутів протягом двох годин, вони в основному належать до випадків ізольованих травм кінцівок та вказують на відсутність ускладнень протягом раннього післятравматичного періоду [8-10].

Особливий інтерес становить розвиток ішеміїреперфузії при поєднаній травмі як наслідок накладання джгутів. Це зумовлено тим, що основним механізмом пошкодження після ішемії-реперфузії 
$€$ генерація активних форм кисню, які ініціюють пероксидне окиснення ліпідів (ПОЛ). Враховуючи недостатність системи антиоксидантного захисту спостерігається системне виражене пошкодження клітинних мембран внаслідок пероксидації їх ліпідного біошару. Вищевказані процеси повинні поглиблюватись на фоні додаткової ішемії, зумовленої поєднаною травмою та супутнім гіповолемічним шоком. Однак ці механізми потребують уточнення та додаткового вивчення.

Мета роботи: вивчити вплив реперфузії кінцівки в моделі поєднаної абдоміно-скелетної травми на зміни показників антиоксидантного захисту у піддослідних тварин.

Матеріали і методи. Робочою гіпотезою експериментального дослідження є припущення, що використання кровоспинного джгута та подальша реперфузія ішемізованих тканин призводить до значних системних змін із порушенням життедіяльності внутрішніх органів при поєднаній абдоміно-скелетній травмі на фоні гіповолемічного шоку, та може стати причиною розвитку змін, що впливають на функцію кісткової тканини.

3 метою реалізації поставленої мети на 130 нелінійних щурах-самцях масою 190-220 г було виконано експериментальне дослідження. Усіх тварин поділили на чотири групи: контрольну (КГ) та три дослідні (ГД): контрольна група (КГ) - інтактні тварини (10 тварин); перша дослідна група (ГД-1) - тварини, яким моделювали перелом стегна, масивну зовнішню кровотечу та ішемію-реперфузію нижніх кінцівок (40 тварин); друга дослідна група (ГД-2) - тварини, яким моделювали скелетну травму, масивну зовнішню крововтрату та закриту травму органів черевної порожнини (40 тварин); третя дослідна група (ГД-3) - тварини, яким моделювали закриту травму органів черевної порожнини, скелетну травму, масивну зовнішню крововтрату та ішемію-реперфузію нижніх кінцівок (40 тварин).

Усі експерименти із нанесення травм виконували в умовах тіопентало-натрієвого знеболення (40 мг·кг-1 маси). Закритий перелом стегнової кістки моделювали шляхом нанесення однократного дозованого удару спеціально розробленим пристроєм по стегну, який викликав закритий перелом - площина ударного пристрою складала 0,5 см², сила удару більше 120 кг/см². Закриту травму органів черевної порожнини моделювали шляхом нанесення двох дозованих ударів в область черевної порожнини спеціально розробленим пристроєм. Завдяки дозованому удару в область черевної порожнини моделюється закрита травма органів черевної порожнини. Сила удару пристрою розрахована таким чином, щоб викликати закриту травму органів черевної порожнини без масивної крововтрати - площина ударного пристрою складала 2,5 см², сила удару не більше 60 кг/см². За таких параметрів виникали внутрішньоорганні гематоми з ушкодженням паренхіми і дрібних внутрішньоорганних кровоносних судин, також виникали забої та невеликі радіальні розриви паренхіматозних органів.

Масивну зовнішню крововтрату моделювали шляхом виконання достатнього операційного доступу до стегнових судин на протилежному від перелому стегнової кістки боці, далі під судинний пучок заводиться лігатура та розсікаються судини. Після цього протягом хвилини (гостра крововтрата) здійснюється забір 20-22 \% циркулюючої крові. Кров забирали шляхом просякання та зважування ватного спонжика. Одразу після відбору достатньої кількості крові кровотечу припиняли шляхом зав’язування лігатур.

В якості кровоспинних джгутів використовували модифікацію широкого еластичного кровоспинного джгута, торговельної марки “SWAT ${ }^{\circledR}$ ", виробництва США. Попередньо перед накладанням 3 оригінального полотна кровоспинного джгута вирізали шматок завширшки 1,5 см та завдовжки 10 см. Достатнє розтягнення джгута, для повного перетискання судин нижньої лапи тварин, контролювали завдяки спеціальним індикаторам, нанесеним виробником на його поверхню.

Тварин виводили з експерименту через 3, 7, 14 та 21 добу після моделювання травм. Під тіопентало-натрієвим знеболенням проводили забій усіх щурів відповідної групи методом тотального кровопускання із серця [13].

У сироватці крові вивчали активність каталази [11]. Враховуючи вміст ТБК-активних продуктів ПОЛ та активність каталази визначали антиоксидантно-прооксидантний індекс (АПІ) [12].

Дослідження зазначених показників визначали в Центральній науковій лабораторії Тернопільського державного медичного університету імені I. Я. Горбачевського.

Вірогідність відмінностей між контрольною і дослідними групами оцінювали з використанням непараметричного критерію Манна-Уїтні. Відмінності вважали істинними при вірогідності нульової гіпотези менше 5 \% $(\mathrm{p}<0,05)$.

Результати досліджень та їх обговорення. За даними наших досліджень, в сироватці крові також спостерігалось збільшення рівня каталази в 
групах піддослідних тварин (табл. 1). Так, аналіз динаміки змін показника каталази в групах дослідження показав, що у ГД-1 через 3 доби він достовірно $(\mathrm{p}<0,05)$ перевищував контрольні показники на 176,4 \%, через 7 діб - на 281,5 \%, через 14 діб - на 323,4 \% та через 21 добу на 378,1 \%. В ГД-2 через 3 доби рівень каталази збільшився на 188,9\% $(\mathrm{p}<0,05)$, через 7 діб збільшився на 311,8 \% ( $<<0,05)$, через 14 діб - на 351,7 \% $(\mathrm{p}<0,05)$ та через 21 добу післятравматичного періоду на 360,1 \% (p<0,05). В ГД-3 за весь час спостереження рівень каталази був достовірно більшим $(\mathrm{p}<0,05)$ контрольних показників через 3 доби на 359,6 \%, через 7 діб на 481,8 \%, через 14 діб - на 341,6 \% та через 21 добу на 162,6 \%.

Порівнюючи показник каталази у дослідних групах за термінами спостереження, виявилося, що в ГД-1 через 3 доби цей показник був меншим, ніж в ГД-3 на 66,3 \% $\left(\mathrm{p}_{1-3}<0,001\right)$ та фактично був на одному рівні з таким у ГД-2. Через 7 діб спостерігалась аналогічна тенденція, показник каталази у ГД-3 був достовірно більшим порівняно з ГД-1 та ГД-2, відповідно, на 52,5 \% $\left(\mathrm{p}_{1-3}<0,001\right)$ та $41,3 \%\left(\mathrm{p}_{2-3}<0,001\right)$. Рівень каталази в ГД-1 був меншим, ніж у ГД-2 на 7,9 \% $\left(\mathrm{p}_{1-2}>0,05\right)$. Через 14 діб післятравматичного періоду у з ГД-1 та ГД-2 спостерігалось зростання показника каталази, у ГД-3, навпаки, його рівень зменшувався. Так, в ГД-3 рівень каталази був статистично більше у ГД-1 на $4,3 \%$, однак менше рівня у ГД-2 та 2,3 \% відповідно $\left(\mathrm{p}_{1-3}>0,05\right.$, $\left.\mathrm{p}_{2-3}>0,05\right)$. Через 21 добу післятравматичного періоду рівень каталази продовжував зменшуватись у ГД-3 порівняно з попереднім показником, тоді як у ГД-1 та ГД-2 він зростав. Так, його рівень в ГД-3 був менше показника у ГД-1 $\left(\mathrm{p}_{1-3}<0,001\right)$ та ГД-2 $\left(\mathrm{p}_{2-3}<0,001\right)$ на 82,1 \% та 75,2 \% відповідно. В ГД-1 та ГД-2 достовірної різниці між показниками не було $\left(\mathrm{p}_{1-2}>0,05\right)$.

Аналізуючи динаміку змін показника каталази у дослідних групах, встановлено (рис. 1), що у ГД-1 показник односпрямовано зростав до 21 доби спостереження. Так, через 7 діб він перевищував рівень через 3 доби на 38,1\% $(\mathrm{p}<0,05)$, до 14 доби його рівень зростав на 10,9 \% (р>0,05) та до 21 доби зріс на 12,9 \% відносно попередніх $(\mathrm{p}<0,05)$. Аналогічна тенденція спостерігалась i у ГД-2, де показник каталази через 7 діб зріс на $42,5 \%(\mathrm{p}<0,05)$ відносно рівня ДК через 3 доби. До 14 доби його рівень зростав відносно рівня через 7 діб на 9,7 \% (р>0,05) та до 21 доби фактично залишався на цьому рівні. В ГД-3 рівень каталази зростав до 7 доби, після чого різко зменшувався до кінця 21 доби: через 7 діб рівень каталази зростав відносно до показника через 3 доби на 26,6 \% ( $<<0,05)$, через 14 діб зменшився на 24,1\% $(\mathrm{p}<0,05)$ та до 21 доби зменшився на 40,5 \% $(\mathrm{p}<0,05)$.

Таким чином, у всіх групах піддослідних тварин спостерігалося значне зростання каталази у всіх контрольних точках спостереження. Якщо у ГД-1 та ГД-2 до 21 доби післятравматичного періоду було односпрямоване зростання його рівня,

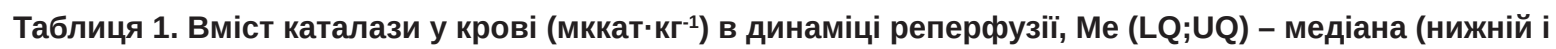
верхній квартилі)

\begin{tabular}{|c|c|c|c|c|c|}
\hline \multirow{2}{*}{$\begin{array}{c}\text { Групи } \\
\text { дослідження }\end{array}$} & \multirow{2}{*}{ Контроль } & \multicolumn{4}{|c|}{ Термін дослідження } \\
\hline & & 3 доба & 7 доба & 14 доба & 21 доба \\
\hline ГД - 1 & \multirow[t]{3}{*}{$\begin{array}{c}4,06 \\
(3,12 ; 4,11) \\
(n=10)\end{array}$} & $\begin{array}{c}11,22^{*} \\
(10,72 ; 12,19) \\
(n=9)\end{array}$ & $\begin{array}{c}15,49^{*} \\
(13,77 ; 17,98) \\
(n=9)\end{array}$ & $\begin{array}{c}17,19^{*} \\
(15,61 ; 17,72) \\
(n=8)\end{array}$ & $\begin{array}{c}19,41^{*} \\
(18,50 ; 19,69) \\
(n=9)\end{array}$ \\
\hline ГД - 2 & & $\begin{array}{c}11,73^{*} \\
(11,33 ; 13,70) \\
(n=8)\end{array}$ & $\begin{array}{c}16,72^{*} \\
(15,58 ; 18,26) \\
(n=8)\end{array}$ & $\begin{array}{c}18,34^{*} \\
(15,89 ; 20,80) \\
(n=8)\end{array}$ & $\begin{array}{c}18,68^{*} \\
(16,44 ; 19,39) \\
(n=8)\end{array}$ \\
\hline ГД - 3 & & $\begin{array}{c}18,66^{*} \\
(17,20 ; 20,16) \\
(n=7)\end{array}$ & $\begin{array}{c}23,62^{*} \\
(22,66 ; 24,51) \\
(n=6)\end{array}$ & $\begin{array}{c}17,93^{*} \\
(16,85 ; 18,27) \\
(n=6)\end{array}$ & $\begin{array}{c}10,66^{*} \\
(9,55 ; 12,21) \\
(n=6)\end{array}$ \\
\hline \multicolumn{2}{|l|}{$\mathrm{p}_{1-2}$} & $>0,05$ & $>0,05$ & $>0,05$ & $>0,05$ \\
\hline \multicolumn{2}{|l|}{$\mathrm{p}_{1-3}$} & $<0,001$ & $<0,001$ & $>0,05$ & $<0,001$ \\
\hline \multicolumn{2}{|l|}{$\mathrm{p}_{2-3}$} & $<0,001$ & $<0,001$ & $>0,05$ & $<0,001$ \\
\hline
\end{tabular}




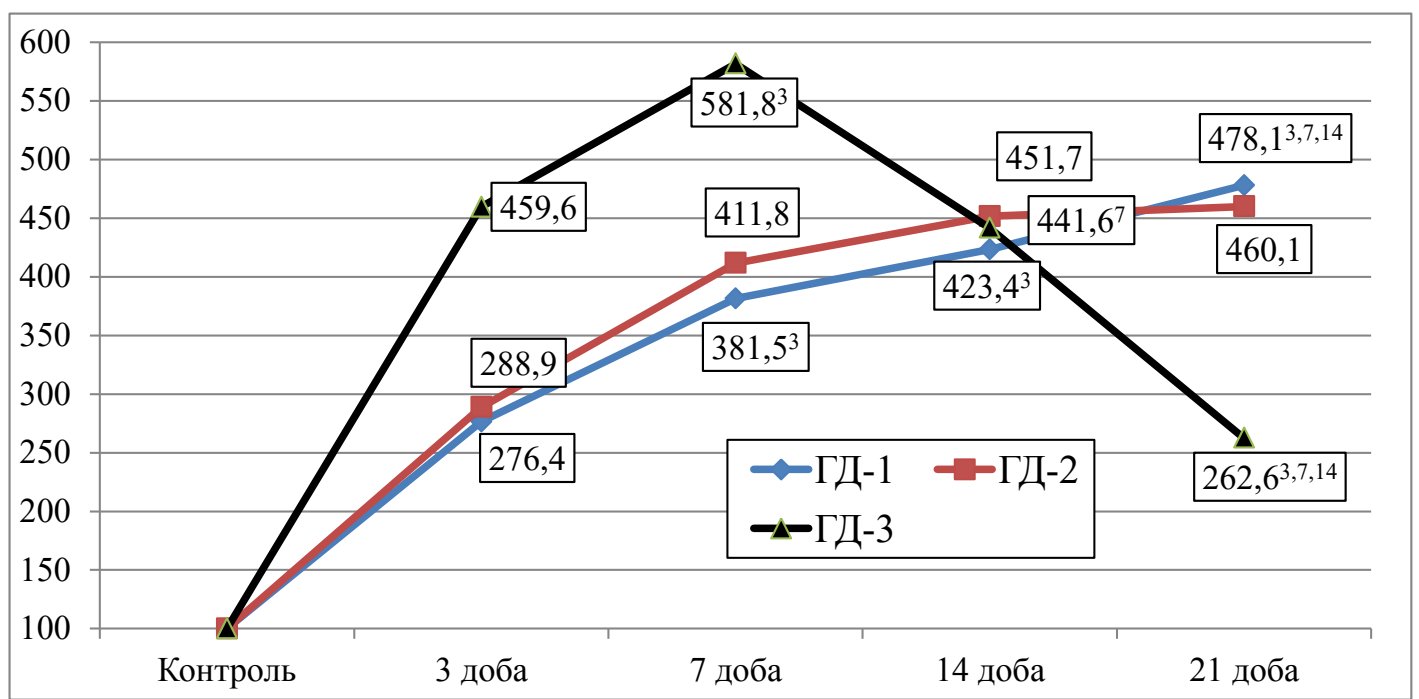

Рис. 1. Динаміка вмісту каталази у сироватці крові (у відсотках від рівня контролю).

що можна інтерпретувати як компенсаторну відповідь на активацію системи ПОЛ, то у ГД-3 після сьомої доби спостереження зафіксували його різке падіння, що може свідчити про її виснаження та ймовірне прогресування системних патологічних змін.

Наведена вище динаміка активності каталази та отримані нами попередньо дані щодо рівня ТБКактивних продуктів ПОЛ ми визначили рівень АПІ (табл. 2). Так, в ГД - 1 рівень АПІ був через три доби на 83,3 \%, через сім діб на 126,7 \%, через 14 діб на 181,6 \% та через 21 добу на 245,1 \% статистич- но більше $(\mathrm{p}<0,05)$ порівняно з показником КГ. У ГД - 2 відповідно на 81,7 \% (p<0,05), на 105,1 \% $(\mathrm{p}<0,05), 135,1 \%(\mathrm{p}<0,05)$ та $145,2 \%(\mathrm{p}<0,05)$ вірогідно більше контролю. На відміну від ГД-1 та ГД-2 рівень АПІ в ГД - 3 зростав до сьомої доби спостереження, після чого зменшувався до 21 доби: через три доби він був на 103,3 \% статистично більше $(\mathrm{p}<0,05)$ контрольних показників, через сім діб на 136,7 \% ( $<0,05)$, через сім діб він різко зменшувався та перевищував контрольні на 70,1 \% ( $<0,05)$, та через 21 добу був статистично менше контрольних показників $(\mathrm{p}<0,05)$ на $13,3 \%$.

Таблиця 2. Вплив реперфузії кінцівки на величину AПІ (ум. од.) в крові, Me (LQ;UQ) - медіана (нижній i верхній квартилі)

\begin{tabular}{|c|c|c|c|c|c|}
\hline \multirow{2}{*}{$\begin{array}{c}\text { Групи } \\
\text { дослідження }\end{array}$} & \multirow{2}{*}{ Контроль } & \multicolumn{4}{|c|}{ Термін дослідження } \\
\hline & & 3 доба & 7 доба & 14 доба & 21 доба \\
\hline ГД - 1 & $\begin{array}{c}0,60 \\
(0,57 ; 0,77) \\
(n=10)\end{array}$ & $\begin{array}{c}1,10^{*} \\
(1,08 ; 1,17) \\
(n=9)\end{array}$ & $\begin{array}{c}1,36^{*} \\
(1,33 ; 1,39) \\
(n=9)\end{array}$ & $\begin{array}{c}1,69^{*} \\
(1,58 ; 1,89) \\
(n=8)\end{array}$ & $\begin{array}{c}2,07^{*} \\
(2,03 ; 2,24) \\
(n=9)\end{array}$ \\
\hline Гд - 2 & & $\begin{array}{c}1,09^{*} \\
(1,07 ; 1,11) \\
(n=8)\end{array}$ & $\begin{array}{c}1,23^{*} \\
(1,16 ; 1,31) \\
(n=8)\end{array}$ & $\begin{array}{c}1,41^{*} \\
(1,36 ; 1,47) \\
(n=8)\end{array}$ & $\begin{array}{c}1,47^{*} \\
(1,41 ; 1,54) \\
(n=8)\end{array}$ \\
\hline ГД - 3 & & $\begin{array}{c}1,22^{*} \\
(1,20 ; 1,24) \\
(n=7)\end{array}$ & $\begin{array}{c}1,42^{*} \\
(1,37 ; 1,47) \\
(n=6)\end{array}$ & $\begin{array}{c}1,02^{*} \\
(0,98 ; 1,06) \\
(n=6)\end{array}$ & $\begin{array}{c}0,52^{*} \\
(0,47 ; 0,59) \\
(n=6)\end{array}$ \\
\hline$p_{1-2}$ & & $>0,05$ & $<0,05$ & $<0,01$ & $<0,001$ \\
\hline $\mathrm{p}_{1-3}$ & & $<0,05$ & $>0,05$ & $<0,001$ & $<0,001$ \\
\hline $\mathrm{p}_{2-3}$ & & $<0,01$ & $<0,01$ & $<0,001$ & $<0,001$ \\
\hline
\end{tabular}


Порівнюючи показник АПІ в дослідних групах за термінами спостереження, виявилося, що в ГД-1 через 3 доби цей показник виявився меншим, ніж в ГД-3 на 10,9 \% $\left(\mathrm{p}_{1-3}<0,05\right)$ та фактично був на одному рівні з таким у ГД-2. Через 7 діб спостерігалась аналогічна тенденція, показник АПІ у ГД-3 був більшим порівняно з ГД-1 та ГД-2 відповідно на 4,4 \% $\left(\mathrm{p}_{1-3}>0,001\right)$ та $15,4 \%\left(\mathrm{p}_{2-3}<0,01\right)$. Рівень АПІ в ГД-1 був більше ніж у ГД-2 на 10,6 \% $\left(\mathrm{p}_{1-2}<0,05\right)$. Через 14 діб післятравматичного періоду у з ГД-1 та ГД-2 спостерігалось зростання показника АПІ, у ГД-3, навпаки, його рівень зменшувався. Так, в ГД-3 рівень АПІ був статистично менше у ГД-1 на $65,7 \%$, та менше рівня у ГД-2 та 38,2 \% відповідно $\left(\mathrm{p}_{1-3}<0,001, \mathrm{p}_{2-3}<0,001\right)$. Рівень АПІ у ГД-1 був достовірно більший, ніж у ГД-2 на 19,9 \% ( $\left.\mathrm{p}_{1-2}<0,01\right)$. Через 21 добу післятравматичного періоду рівень АПІ продовжував зменшуватись у ГД-3 порівняно 3 попереднім показником та був достовірно менший, ніж у контрольній групі, тоді як у ГД-1 та ГД-2 він зростав. Так, його рівень в ГД-3 був менше показника у ГД-1 $\left(\mathrm{p}_{1-3}<0,001\right)$ та ГД-2 $\left(\mathrm{p}_{2-3}<0,001\right)$ на $74,9 \%$ та $64,6 \%$ відповідно. В ГД-1 показник був достовірно більший, ніж у ГД-2 на 28,9 \% ( $\left.\mathrm{p}_{1-2}<0,001\right)$.

Аналізуючи динаміку змін показника АПІ в дослідних групах встановлено (рис. 2), що у ГД-1 показник односпрямовано зростав до 21 доби спостереження. Так, через 7 діб він перевищував рівень через 3 доби на 23,6 \% $(\mathrm{p}<0,05)$, до 14 доби його piвень зростав на 24,3 \% $(\mathrm{p}<0,05)$ та до 21 доби зріс на 22,5 \% відносно попередніх ( $<0,05)$. Аналогічна тенденція спостерігалась і у ГД-2, де показник АПІ через 7 діб зріс на $12,8 \%(\mathrm{p}<0,05)$ відносно рівня через 3 доби. До 14 доби його рівень зростав відносно рівня через 7 діб на 14,6 \% $(\mathrm{p}<0,05)$ та до 21 доби фактично залишався на рівні через 14 діб. В ГД-3 рівень АПІ зростав до 7 доби, після чого різко зменшувався до кінця 21 доби: через 7 діб рівень АПІ зростав відносно показника через 3 доби на 16,4 \% $(\mathrm{p}<0,05)$, через 14 діб зменшився на 28,2 \% $(\mathrm{p}<0,05)$ та до 21 доби зменшився на 49,0 \% $(\mathrm{p}<0,05)$.

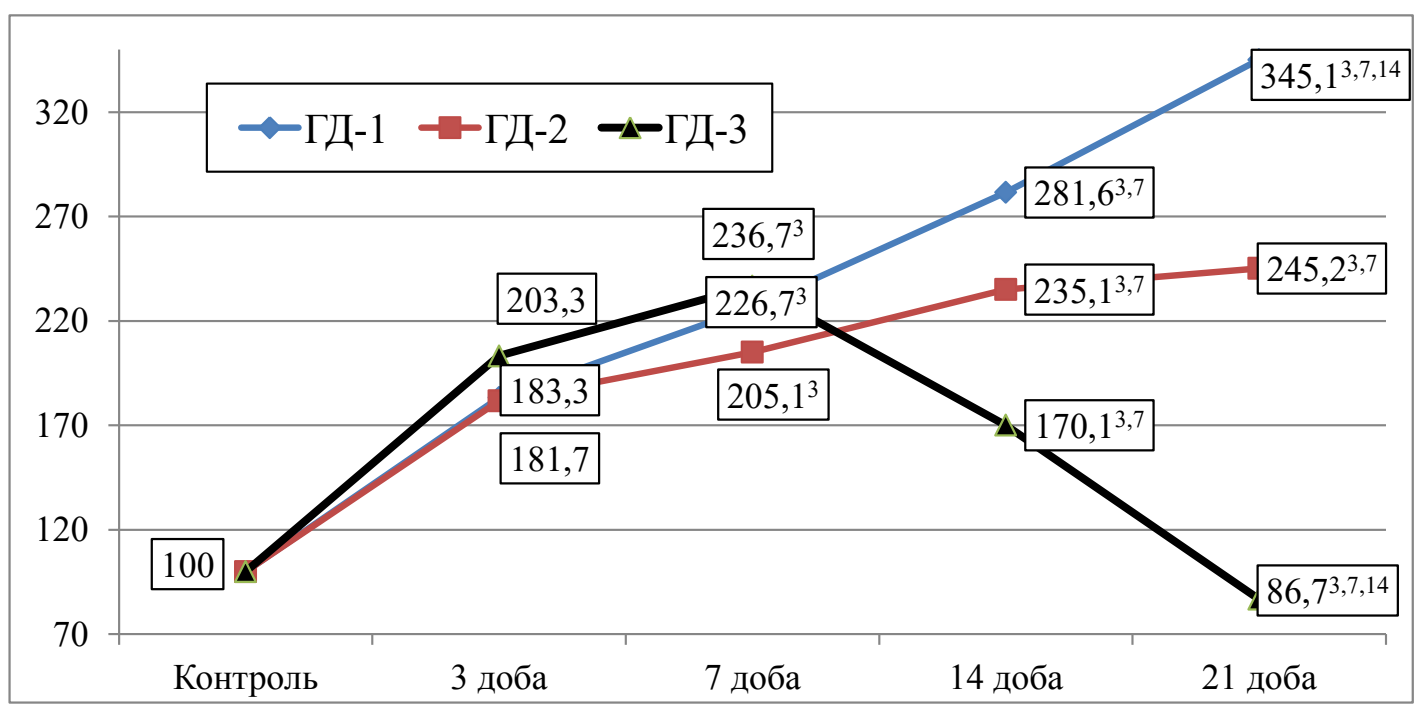

Рис. 2. Динаміка вмісту АПІ в сироватці крові (у відсотках від рівня контролю).

Таким чином АПІ, який вказує на наявний баланс прооксидантних і антиоксидантних механізмів, не нормалізувався у групах піддослідних тварин до кінця часу проведення експерименту. Такі результати вказують на те, що поєднана травма викликає тривалі системні зміни та дисбаланс адаптаційно-компенсаторних механізмів, спрямованих на ліквідацію патологічних чинників.

Як показав аналіз результатів, поєднання закритої травми органів черевної порожнини, ске- летної травми та ішемії реперфузії [14] нижніх викликає тривалий оксидативний стрес та виснаження антиоксидантних систем, про що свідчить зниження рівня АПІ.

Висновки. 1. У всіх групах піддослідних тварин спостерігалося значне зростання у всіх контрольних точках спостереження рівня каталази. Найбільша динаміка змін спостерігалась у групі піддослідних тварин, в яких моделювали закриту травму 
органів черевної порожнини, скелетну травму, масивну зовнішню крововтрату та ішемію-реперфузію нижніх кінцівок. Так, рівень каталази у них був найвищим через 7 діб у післятравматичному періоді та перевищувала контрольні у 5,8 раза $(\mathrm{p}<0,05)$, та до 21 доби різко зменшувався та був більше контрольних у 2,6 раза ( $<<0,05)$. Вищевказане свідчило про виснаження системи прооксидантної системи.

2. Отримані результати свідчать про розвиток значного дисбалансу прооксидантних і антиоксидантних механізмів, про що свідчить динамі-

\section{СПИСОК ЛІТЕРАТУРИ}

1. Trends in 1029 trauma deaths at a level 1 trauma center / B. T. Oyeniyi, E. E. Fox, M. Scerbo [et al.] // Injury. - 2017. Vol. 48 (1). - P. 5-12.

2. Bellamy R. F. Causes of death in conventional warfare: implications for combat casualty care research / R. F. Bellamy // Mil. Med. - 1984. - No. 149. - P. 55-62.

3. Trends in 1029 trauma deaths at a level 1 trauma center / B. T. Oyeniyi, E. E. Fox, M. Scerbo [et al.] // Injury. - 2017. Vol. 48 (1). - P. 5-12.

4. An evidence-based prehospital guideline for external hemorrhage control: American College of Surgeons Committee on Trauma / E. M. Bulger, D. Snyder, K. Schoelles [et al.] // Prehosp. Emerg. Care. - 2014. - No. 18. - P. 163-173.

5. Haemorrhage control in severely injured patients / R. L. Gruen, K. Brohi, M. Schreiber [et al.] // Lancet. - 2012. N. 380. - P. 1099-1110.

6. Ratnasekera A. Damage control resuscitation in surgical critical care / A. Ratnasekera, P. Reilly, P. Ferrada // In the book: Damage Control in Trauma Care; J. C. Duchesne, K. Inaba, M. A. Khan (Eds.); chapter 15. Springer, AG, 2018.

7. Maegele M. The acute coagulopathy of trauma: mechanisms and tools for risk stratification / M. Maegele, P. Spinella, H. Schöchl // Shock. - 2012. - No. 38. - P. 450-458.

8. New effective tourniquets for potential use in the military environment: A serving soldier study / A. Beaven, R. Briard, M. Ballard, P. Parker // Military Medicine. - 2017. - Vol. 182 (7). - P. 1929-1932.

\section{REFERENCES}

1. Oyeniyi, B.T., Fox, E.E., Scerbo, M., Tomasek, J.S., Wade, C.E., \& Holcomb, J.B. (2017). Trends in 1029 trauma deaths at a level 1 trauma center. Injury, 48 (1), 5-12.

2. Bellamy, R.F. (1984). Causes of death in conventional warfare: implications for combat casualty care research. Mil. Med., 149, 55-62.

3. Oyeniyi, B.T., Fox, E.E., Scerbo, M., Tomasek, J.S., Wade, C.E., \& Holcomb, J.B. (2017). Trends in 1029 Trauma deaths at a level 1 trauma Ccenter. Injury, 48 (1), 5-12.

4. Bulger, E.M., Snyder, D., Schoelles, K., Gotschall, C., Dawson, D., Lang, E., ..., \& McSwain, N.Jr. (2014). An evidence-based prehospital guideline for external hemorrhage control: American College of Surgeons Committee on Trauma. Prehosp. Emerg. Care, 18, 163-173. ка вмісту антиоксидантно-прооксидантного індексу, який до 21 доби спостереження зростав у ГД-1 та ГД-2 та перевищував контрольні на 245,1 \% $(\mathrm{p}<0,05)$ та 145,2 \% ( $<<0,05)$, відповідно, у ГД-3 він зменшувався та був в цей період менше контрольних у 13,3 \% $(\mathrm{p}<0,05)$.

Перспективи подальших досліджень. У перспективі передбачається розробити патогенетично обгрунтовані засоби корекції системних змін, що виникають під впливом реперфузії кінцівки.

9. Epidemiology of mass casualty incidents in the United States / E. Schenk, G. Wijetunge, N. Mann [et al.] // Prehospital Emergency Care. - 2014 - Vol. 18 (3). - P. 408-416.

10. King D. R. Tourniquet use at the Boston Marathon bombing: Lost in translation / D. R. King, A. Larentzakis, E. P. Ramly // Journal of Trauma and Acute Care Surgery. - 2015. - Vol. 78 (3). - P. 594-599.

11. Метод определения активности каталазы / М. А. Королюк, Л. И. Иванова, И. Г. Майорова, В. Е. Токарев // Лабораторное дело. - 1988. - № 1. - С. 16-19.

12. Антиоксидантно-прооксидантний індекс сироватки крові щурів з експериментальним стоматитом і його корекція зубними еліксирами / А. П. Левицький, В. М. Почтар, О.А. Макаренко, Л. І. Гридіна // Одеський мед. журн. - 2006. - № 1. - C. 22-25.

13. Protective properties of microcrystalline cellulose in rats with experimental diabetes / S. G. Vainshtein, I. V. Zhulkevich, G. A. Petropavlovskii, N. E. Kotelnikova // Bulletin of Experimental Biology and Medicine. - 1987. - Vol. 103, Issue 2. - P. 186-188.

14. Volotovska N. V. Changes in the glutathione system's activity of internal organs in the first hours of experimental limb ischemiareperfusion syndrome, combined with blood loss and mechanical injury / N. V. Volotovska, T. C. Nhokwara, I. V. Zhulkevych // Здобутки клінічної і експериментальної медицини. - 2019. № 1. - C. 23-27. DOI 10.11603/1811-2471.2019.v0.i1.10043

5. Gruen, R.L., Brohi, K., Schreiber, M., Balogh, Z.J., Pitt, V., Narayan, M., \& Maier, R.V. (2012). Haemorrhage control in severely injured patients. Lancet, 380, 1099-1110.

6. Ratnasekera, A., Reilly, P. \& Ferrada, P. (2018). Damage control resuscitation in surgical critical care. Damage Control in Trauma Care. Duchesne, J.C., Inaba, K., Khan, M.A. (Eds.). Chapter 15. Springer, AG.

7. Maegele, M., Spinella, P., \& Schöchl, H. (2012). The acute coagulopathy of trauma: mechanisms and tools for risk stratification. Shock, 38, 450-458.

8. New effective tourniquets for potential use in the military environment: A serving soldier study / A. Beaven, R. Briard, M. Ballard, P. Parker (2017) // Mil. Med., 182 (7), 1929-1932.

9. Schenk, E., Wijetunge, G., Mann, N.C., Lerner, E.B., Longth 
orne, A., \& Dawson, D. (2014). Epidemiology of mass casualty incidents in the United States. Prehospital Emergency Care, 18 (3), 408-416.

10. King, D.R., Larentzakis, A., \& Ramly, E.P. (2015). Tourniquet use at the Boston Marathon bombing: Lost in translation. Journal of Trauma and Acute Care Surgery, 78 (3), 594-599.

11. Korolyuk, M.A., Ivanova, L.I., Mayorova, I.G., \& Tokarev, V. Ye. (1988). Metod opredeleniya aktivnosti katalazy [Method for determination of catalase activity]. Laboratornoye delo - Laboratory Case, 1, 16-19 [in Russian].

12. Levytskyi, A.P., Pochtar, V.M., Makarenko, O.A., \& Hrydina, L.I. (2006). Antyoksydantno-prooksydantnyi indeks syrovatky krovi shchuriv z eksperymentalnym stomatytom i yoho korektsiia zubnymy eliksyramy [Antioxidant-prooxidant index of serum of rats with experimental stomatitis and its correction with dental elixirs]. Odeskyi med. zhurn. - Odesa Medical Journal, 1, 22-25 [in Ukrainian].

13. Vainshtein, S.G., Zhulkevich, I.V., Petropavlovskii, G.A., \& Kotelnikova, N.E. (1987). Protective properties of microcrystalline cellulose in rats with experimental diabetes. Bulletin of Experimental Biology and Medicine, 103 (2), 186-188.

14. Volotovska, N.V., Nhokwara, T.C., \& Zhulkevych, I.V. (2019). Changes in the glutathione systems activity of internal organs in the first hours of experimental limb ischemiareperfusion syndrome, combined with blood loss and mechanical injury. Zdobutky klinichnoi i eksperymentalnoi medytsyny Achievements of Clinical and Experimental Medicine, 1, 23-27. DOI 10.11603/1811-2471.2019.v0.i1.10043

Отримано 24.09.2019

\section{S. V. GARIAN}

Ukrainian Scientific and Practical Center of Emergency and Disaster Medicine, Ministry of Health of Ukraine, Kyiv

\section{CHANGES OF ANTIOXIDANT SYSTEM IN EXPERIMENTAL ANIMALS AFTER COMBINED ABDOMINO-SKELETAL TRAUMA AND ISCHEMIA REPERFUSION OF THE LOWER EXTREMITIES}

The aim of the work: to study the effect of limb reperfusion in a model of combined abdomino-skeletal injury on changes in antioxidant protection in experimental animals.

Materials and Methods. The experiment used 130 adult white male Wistar rats weighing 190-220 g, which were on a standard diet of vivarium.

All animals were divided into groups: control (CG) and three experimental (EG): control group - intact animals (10 animals); first experimental group (EG-1) - simulated hip fracture, massive external bleeding and lower limb ischemia-reperfusion (40 animals); second experimental group (EG-2) - modeled hip fracture, massive external blood loss and closed trauma of abdominal organs (40 animals); the third experimental group (EG-3) - modeled closed abdominal trauma, skeletal trauma, massive external blood loss, and lower extremity ischemia-reperfusion (40 animals).

The animals of the experimental groups were removed from the experiment under conditions of thiopental sodium anesthesia by total blood flow from the heart 3, 7, 14 and 21 days after trauma modeling. Animal blood was collected for the study.

The activity of catalase was determined in the serum, and the antioxidant-prooxidant index was calculated based on previously obtained data on the content of reagents to thiobarbituric acid (TBA-active products).

Results and Discussion. The results suggest that limb reperfusion causes the development of prolonged oxidative stress in response to increasing catalase levels. The most pronounced changes were observed in the group of experimental animals, where ischemia of lower extremity reperfusion was present along with the combined abdominal-skeletal injury. It was it that caused the development of long-lasting systemic changes and, accordingly, an imbalance of adaptation-compensatory mechanisms aimed at eliminating pathological factors.

The combination of abdominal-skeletal trauma and ischemia of lower reperfusion causes prolonged oxidative stress and depletion of antioxidant systems, as evidenced by a decrease in the level of API, which after 21 days was statistically less than the control values (p <0.05) by $13.3 \%$.

Key words: ischemia; reperfusion; tourniquet; experiment; combined trauma; catalase; bleeding. 


\author{
С. В. ГАРИЯН
}

Государственное учреждение "Украинский научно-практический центр экстренной медицинской помощи и медицины катастроср МОЗ Украины", Киев

\title{
СОСТОЯНИЕ СИСТЕМЫ АНТИОКСИДАНТНОЙ ЗАЩИТЫ У ПОДОПЫТНЫХ ЖИВОТНЫХ В РЕЗУЛЬТАТЕ МОДЕЛИРУЕМОЙ СОЧЕТАННОЙ АБДОМИНО-СКЕЛЕТНОЙ ТРАВМЫ И ИШЕМИИ-РЕПЕРФУЗИИ НИЖНИХ КОНЕЧНОСТЕЙ
}

Цель работы: изучить влияние реперфузии конечности в модели сочетанной абдомино-скелетной травмы на изменения показателей антиоксидантной защиты.

Материалы и методы. В эксперименте использовали 130 половозрелых белых крыс-самцов линии Wistar массой 190-220 г, которые находились на стандартном рационе вивария.

Подопытных животных разделили на следующие группы: контрольную (КГ) и три опытных (ГД): контрольная группа - интактные животные (10 животных); первая группа исследования (ГИ-1) - моделировали перелом бедра, массивное наружное кровотечение и ишемию-реперфузию нижних конечностей (40 животных); вторая группа исследования (ГИ-2) - моделировали перелом бедра, массивную внешнюю кровопотерю и закрытую травму органов брюшной полости (40 животных); третья группа исследования (ГИ-3) - моделировали закрытую травму органов брюшной полости, скелетную травму, массивную внешнюю кровопотерю и ишемию-реперфузию нижних конечностей (40 животных).

Животных опытных групп выводили из эксперимента в условиях тиопентал-натриевого наркоза методом тотального кровопускания из сердца через 3, 7, 14 и 21 сутки после моделирования травм. Для исследования собирали кровь животных.

В сыворотке крови определяли активность каталазы, и учитывая полученные предварительно данные по содержанию реагентов к тиобарбитуровой кислоте (ТБК-активных продуктов), рассчитывали антиоксидантно-прооксидантный индекс.

Результаты исследований и их обсуждение. Полученные результаты позволяют утверждать, что реперфузия конечности вызывает развитие длительного оксидативного стресса, что проявляется нарастанием уровня каталазы. Наиболее выраженные изменения зафиксированы в группе подопытных животных, где наряду с сочетанной абдомино-скелетной травмой присутствовала ишемия-реперфузия нижних конечностей. Именно она была причиной развития длительных системных изменений и соответственно дисбаланса адаптационно-компенсаторных механизмов, направленных на ликвидацию патологических факторов.

Сочетание абдомино-скелетной травмы и ишемии-реперфузии нижних конечностей вызывает длительный оксидативный стресс и истощение антиоксидантных систем, о чем свидетельствует снижение уровня АРІ, который через 21 день был статистически меньше контрольных показателей (р <0,05) на 13,3 \%

Ключевые слова: ишемия; реперфузия; жгут; эксперимент; сочетанная травма; каталаза; кровотечение. 